\title{
Peran Insecure Attachment terhadap Kekerasan Psikologis dalam Pacaran pada Perempuan Remaja Akhir
}

\author{
Arlin Aulia Andayu, Charyna Ayu Rizkyanti, Sri Juwita Kusumawardhani \\ Fakultas Psikologi Universitas Pancasila, Jakarta, Indonesia \\ e-mail: charyna@univpancasila.ac.id
}

\begin{abstract}
The issues of dating violence take public attention recently. Psychological violence in a romantic relationship is one type of violence that has a serious impact on victims where women are more likely to experience it. Attachment is one of the risk factors that contributed to violence in romantic relationships. The aim of this study is to determine whether insecure attachment (preoccupied, dismissive, and fearful avoidant) influence female vulnerability to become victims of psychological violence in a romantic relationship. The participants were 393 female late adolescents in Jakarta. Multiple regression analysis shows that insecure attachment impact significantly to the vurnerability of becoming victim in psychological violence in romantic relationships among female late adolescents.
\end{abstract}

Keywords: dating violence, psychological violence, insecure attachment

\begin{abstract}
Abstrak
Fenomena kekerasan dalam pacaran (KDP) menjadi perhatian publik akhir- akhir ini. Salah satu jenis kekerasan dalam pacaran yang menimbulkan dampak serius pada korban adalah kekerasan psikologis dimana KDP banyak menimpa perempuan. Attachment merupakan salah satu faktor risiko yang berkontribusi pada kekerasan dalam pacaran. Penelitian ini bertujuan untuk melihat apakah insecure attachment yang terdiri dari preoccupied, dismissive, dan fearful avoidant memengaruhi kerentanan perempuan remaja akhir untuk menjadi korban kekerasan psikologis dalam pacaran. Metode penelitian menggunakan kuantitatif korelasional. Subjek penelitian terdiri dari 393 perempuan remaja akhir di Jakarta. Hasil analisis regresi berganda menunjukkan bahwa insecure attachment berpengaruh signifikan terhadap kerentanan perempuan remaja akhir untuk menjadi korban kekerasan psikologis dalam pacaran.
\end{abstract}

Kata Kunci: kekerasan dalam pacaran, kekerasan psikologis, insecure attachment

\section{Pendahuluan}

Kekerasan dalam pacaran merupakan masalah sosial yang menjadi perhatian akhir-akhir ini. Pacaran pada remaja idealnya merupakan sebuah proses pembentukan dan membangun hubungan personal dengan lawan jenis yang di dalamnya melibatkan rasa kasih sayang (Papalia \& Feldman, 2014). Akan tetapi, perbedaan latar belakang yang dimiliki individu dapat berpotensi menjadi konflik.

Konflik yang berkembang dalam sebuah hubungan dapat menjadi pembelajaran positif jika dapat terselesaikan dengan baik. Salah satu hal yang membuat konflik tidak terselesaikan dengan baik disebabkan oleh rendahnya kemampuan remaja dalam meregulasi emosi (Exner-Cortens, 2018). Akibatnya, dalam hubungan akan muncul emosi negatif. Pelampiasan emosi yang tidak tepat menyebabkan pacaran digunakan untuk menyakiti pasangan dengan melakukan perilaku-perilaku kekerasan. Faktanya, usia berhubungan dengan terjadinya kekerasan dalam pacaran (Millet dkk., 2015).

Kasus kekerasan dalam pacaran banyak terjadi pada individu dalam tahapan perkembangan remaja akhir. Khaninah dan Wijanarko (2015) menyatakan bahwa tingkat risiko tertinggi kekerasan dalam pacaran berada pada usia 16-19 tahun. Pada 
tahap perkembangan remaja akhir, para remaja mulai menganggap bahwa berpacaran adalah hal yang lebih serius dan penuh tekanan. Oleh sebab itu, memungkinkan bagi remaja untuk melakukan kekerasan dalam pacaran akibat tekanan yang muncul selama proses pacaran.

Komnas Perempuan (2017) menyatakan bahwa kasus kekerasan dalam pacaran (KDP) pada 2016-2017 terbilang tinggi, yaitu berada di atas 2000 kasus pertahunnya. Pada tahun 2017, kasus KDP mencapai 2171 kasus. KDP adalah perilaku yang dilakukan untuk mengontrol dan mendominasi baik secara fisik, seksual, dan psikologis yang membahayakan pasangan (Wolfe \& Feiring, 2002).

Kekerasan psikologis merupakan jenis kekerasan dalam pacaran yang memiliki dampak serius pada korban. Kekerasan psikologis dalam pacaran adalah segala bentuk kekerasan nonfisik yang bersifat manipulatif dan dilakukan dengan sengaja (Stark, 2015). Perilaku tersebut ditujukan untuk mengontrol, mendominasi, mengancam, dan membatasi pergaulan pasangan (Wekerle \& Wolfe, 1999).

Riset terkait kekerasan psikologis menunjukkan tingginya prevalensi kekerasan psikologis dibandingkan jenis kekerasan lain. Sebesar $80 \%$ dari kasus kekerasan dalam pacaran merupakan kekerasan psikologis (Cortes-Ayala dkk., 2014). Wolfe dkk. (2001) membagi kekerasan psikologis menjadi beberapa dimensi yaitu agresi relasi, perilaku mengancam, dan verbal atau emosional.

Agresi relasi merupakan perilaku yang bertujuan untuk mengontrol sosial atau merusak hubungan antara pelaku dengan korban maupun korban dengan lainnya atau lingkungannya. Perilaku mengancam diartikan sebagai perilaku membuat pasangan merasa terancam atau menakutnakuti baik secara fisik, seksual, maupun psikologis. Verbal atau emosional adalah kekerasan yang dilakukan dengan cara menghina, mengejek atau menertawakan, mengungkapkan kesalahan yang terjadi di masa lalu, menyalahkan, dan membuat pasangan marah atau cemburu yang bertujuan untuk melukai psikologis pasangan.

Temple dkk. (2016) menyatakan bahwa kekerasan psikologis yang dialami seseorang dapat memberikan dampak yang berat pada orang tersebut. Secara umum dampak dari kekerasan psikologis dapat menggerus self esteem korban, membuat korban ketakutan, tidak memiliki power, depresi, kebingungan, merasa tidak berharga, dan tidak memiliki harapan (Stark, 2015). Meskipun penelitian tentang kekerasan dalam pacaran sudah banyak dilakukan, namun hanya sedikit yang membahas mengenai kekerasan psikologis, padahal dampak dari kekerasan ini sangat berbahaya.

Hingga saat ini, penelitian terkait kekerasan dalam pacaran lebih banyak berfokus pada kekerasan fisik (Temple dkk., 2016). Perhatian yang minim pada kekerasan psikologis menjadikan individu kurang waspada dan sadar akan bentuk kekerasan psikologis. Salah satu penyebabnya karena kekerasan ini tidak meninggalkan bekas yang terlihat seperti pada kekerasan fisik dan jenis kekerasan lain (Urena dkk., 2015).

Laki-laki maupun perempuan dapat menjadi korban atau pelaku kekerasan dalam pacaran. Laki-laki cenderung menjadi pelaku dari kekerasan dalam pacaran (Reyes dkk., 2016) dan perempuan lebih banyak menjadi korban kekerasan dalam hubungan romantis (Alvarez, 2014; Jennings dkk., 2017; Wang, 2016). Perempuan yang pernah mengalami kekerasan dalam pacaran memiliki risiko untuk mengalami hal tersebut di kemudian hari (Taskale \& Soygut, 2016). Oleh sebab itu, penting untuk memutus rantai tersebut. Salah satu teori yang dapat digunakan untuk menjelaskan faktor risiko terkait kekerasan dalam pacaran adalah teori attachment (Tussey dkk., 2018; Ulloa dkk., 2014). 
Konsep attachment pertama kali dikenalkan oleh Bowlby (1983) dijelaskan bahwa attachment adalah ikatan psikologis yang kuat antara anak dengan figur lekat atau orang terdekat seperti orang tua maupun pengasuh. Namun, seiring perubahan perkembangan, figur lekat seorang anak yang tadinya berpusat pada caregiver-nya, di masa dewasa dapat berubah menjadi pada pasangannya (Hazan \& Shaver, 1994). Penelitian ini berfokus pada attachment remaja dengan pasangan dalam relasi romantis sebagai figur lekat atau dikenal dengan adult attachment.

Adult attachment adalah ikatan emosional yang kuat antara seseorang dengan pasangan sebagai figur lekat (Bartholomew, 1990). Bartholomew (1990) membagi attachment style menjadi empat jenis, yaitu: secure attachment dan insecure attachment yang terdiri dari fearful avoidant, preoccupied, dan dismissive. Namun penelitian ini hanya menggali insecure attachment sebab secara teoretis insecure attachment lebih berperan dalam kekerasan dalam suatu relasi. Hal ini disebabkan individu dengan insecure attachment memiliki kesulitan untuk melakukan manajemen konflik dengan baik sehingga memungkinkan untuk menyelesaikan konflik dengan melibatkan perilaku kekerasan salah satunya kekerasan psikologis dalam pacaran (Lee dkk., 2014).

Insecure attachment merupakan derajat seseorang memandang diri sendiri dan orang lain baik, dimana setidaknya terdapat salah satu aspek negatif pada cara memandang diri (model of self) maupun orang lain (model of others) dimana terbagi menjadi tiga jenis yaitu preoccupied, dismissive, dan fearful avoidant attachment (Bartholomew, 1990). Bartholomew dan Horowitz (1991) membagi insecure attachment menjadi dua dimensi yaitu anxiety dan avoidance. Anxiety dicirikan dengan adanya rasa takut akan pengabaian dari orang lain termasuk pasangan dalam relasi romantis. Avoidance dicirikan dengan kecenderungan menghindar dari orang lain, baik dalam hubungan romantis maupun pertemanan. Attachment pada masa sebelumnya dan penghayatan seseorang terhadap relasinya dengan pasangan menjadi faktor yang memengaruhi attachment yang dimiliki (Bartholomew, 1990).

Penelitian terkait insecure attachment dan KDP belum banyak dilakukan di Indonesia. Beberapa penelitian yang ada hanya membahas attachment dan KDP secara umum dari sudut pandang pelaku. Penelitian yang dilakukan oleh Purnomo dan Suryadi (2017) menunjukkan bahwa individu dengan fearful avoidant memiliki kecenderungan lebih tinggi untuk melakukan kekerasan dalam pacaran.

Diadiningrum dan Endrijati (2014) melakukan penelitian terkait kecenderungan menjadi korban kekerasan dalam pacaran namun tidak dikaitkan dengan attachment, melainkan dengan sikap asertivitas dengan hasil semakin tinggi asertivitas maka semakin rendah kecenderungan menjadi korban kekerasan dalam pacaran. Melihat masih terbatasnya penelitian terkait attachment dan kekerasan psikologis yang dilihat dari sudut pandang korban, peneliti tertarik untuk meneliti pengaruh insecure attachment terhadap kekerasan psikologis dalam pacaran pada perempuan remaja akhir.

Penelitian ini berfokus pada kemungkinan seseorang untuk menjadi korban karena korbanlah yang secara langsung merasakan dampak dari kekerasan yang dialami. Berdasarkan penjelasan di atas, peneliti akan menguji apakah perbedaan insecure attachment yang dimiliki dapat memprediksi kerentanan perempuan remaja akhir untuk menjadi korban kekerasan psikologis dalam pacaran.

\section{Metode Penelitian}

Metode penelitian menggunakan kuantitatif korelasional. Sampel dalam penelitian ini adalah remaja akhir yang tinggal di Jakarta berusia 16-20 tahun yang 
sedang atau pernah berpacaran $(\mathrm{N}=393)$. Teknik pengambilan menggunakan accidental sampling dengan alasan kemudahan dan aksesibilitas dalam mendapatkan sampel sehingga diharapkan mendapatkan banyak sampel agar dapat merepresentasikan populasi.

Penelitian ini menggunakan kuesioner yang disebarkan secara online. Alat ukur dalam penelitian ini telah diuji validitas dan reliabilitasnya. Batasan penelitian ini menggunakan $\geq .30$ untuk menyatakan bahwa item telah valid (Anastasi \& Urbina, 2007; Azwar, 2016).

Insecure attachment diukur menggunakan skala Adolescents Relationship Scales Questionnaire sebagai hasil revisi dari alat ukur Relationship Scales Questionnaire yang dikembangkan oleh Griffin dan Bartholomew (1994) dengan jumlah item sebanyak 12. Dari 12 item tersebut, terdapat 10 item yang telah memenuhi kriteria validitas item dengan rentang .397 sampai dengan .740. Alat ukur ini mengukur tiga dimensi yaitu preoccupied $(\alpha=.794)$ dengan contoh item: "Saya ingin sepenuhnya dekat secara emosional dengan pacar saya". Dimensi berikutnya dismissive $(\alpha=.728)$ dengan contoh item: "Sangat penting bagi saya untuk menjadi pribadi yang mandiri", dan dimensi terakhir yaitu fearful avoidant $(\alpha=$ .734) dengan contoh item: "Sulit bagi saya untuk mengandalkan pacar saya".

Kekerasan psikologis dalam pacaran diukur menggunakan Conflict in Adolescent Dating Relationship Inventory (CADRI) yang dikembangkan oleh Wolfe dkk. (2001) dan telah diadaptasi melalui proses translasi dan translasi ulang dengan total 17 item $(\alpha=.939)$ yang terbagi dalam 3 dimensi yaitu agresi relasi $(\alpha=.922)$ dengan contoh item: "Dia mencoba untuk membuat teman-teman saya tidak menyukai saya". Dimensi berikutnya yaitu perilaku mengancam $(\alpha=.825)$ dengan contoh item: "Dia merusak atau mengancam untuk menghancurkan harga diri saya", dan dimensi terakhir yaitu kekerasan verbal atau emosional $(\alpha=.919)$ dengan contoh item: "Dia melakukan sesuatu untuk membuat saya cemburu". Seluruh item yang terdapat pada alat ukur telah memenuhi kriteria validitas dengan rentang .532 sampai dengan .835 .

Teknik analisis data menggunakan analisis regresi linier berganda untuk mengetahui besar pengaruh dari insecure attachment (preoccupied, dismissive, fearful avoidant) terhadap kekerasan psikologis dalam pacaran pada perempuan remaja akhir.

\section{Hasil Penelitian dan Pembahasan}

Berdasarkan tabel 1 dapat disimpulkan bahwa sebesar $11.8 \%$ nilai kerentanan perempuan remaja akhir untuk mejadi korban kekerasan psikologis dalam pacaran dipengaruhi oleh insecure attachment dan sisanya dipengaruhi faktor lain yang tidak terdapat dalam penelitian. Adapun signifikansi yang diperoleh sebesar .000 ( $p<.05)$ sehingga hipotesis nol ditolak. Artinya, insecure attachment berpengaruh secara signifikan terhadap kerentanan perempuan remaja akhir untuk menjadi korban kekerasan psikologis dalam pacaran sebesar 11.8\%. Berdasarkan tabel 2 didapatkan nilai koefisien regresi variabel fearful avoidant sebesar 2.530 dengan signifikansi .000 artinya variabel tersebut memengaruhi kekerasan psikologis dalam pacaran.

Tabel 1

Hasil Uji Regresi Simultan Insecure Attachment dan Kekerasan Psikologis dalam Pacaran

\begin{tabular}{rccc}
\hline$R$ & $R$ Square & $F$ & Sig \\
\hline $.344^{\mathrm{a}}$ & .118 & 17.425 & .000 \\
\hline
\end{tabular}

Tabel 2

Hasil Uji Regresi Parsial Insecure Attachment dan Kekerasan Psikologis dalam Pacaran

\begin{tabular}{lccc}
\hline \multicolumn{1}{c}{ Model } & $\begin{array}{c}\text { Unstandardized } \\
\text { Coefficients B }\end{array}$ & $\begin{array}{c}\text { Standardized } \\
\text { Coefficients }\end{array}$ & Sig \\
\hline (Constant) & -.397 & & .832 \\
Fearful & 2.530 & .296 & .000 \\
avoidant & & & \\
Dismissive & -1.123 & -.124 & .013 \\
Preoccupied & 1.676 & .142 & .004 \\
\hline
\end{tabular}


Dalam Tabel 2 pengaruh variabel $(B=$ 2.530, $p=.000$ ) dengan arah pengaruh positif sehingga dapat dikatakan semakin tinggi fearful avoidant maka semakin tinggi pula kerentanan perempuan remaja akhir untuk menjadi korban kekerasan psikologis dalam pacaran. Koefisien regresi dari variabel preoccupied sebesar 1.676 dengan signifikansi .004 artinya variabel tersebut secara positif memengaruhi kerentanan perempuan remaja akhir untuk menjadi korban kekerasan psikologis dalam pacaran $(B=1.676, p=.004)$. Artinya, semakin tinggi preoccupied semakin tinggi pula kerentanan perempuan remaja akhir untuk menjadi korban kekerasan psikologis dalam pacaran. Koefisien regresi variabel dismissive sebesar -1.123 dengan signifikansi .013 artinya variabel tersebut berpengaruh negatif signifikan terhadap kerentanan perempuan remaja akhir untuk menjadi korban kekerasan psikologis dalam pacaran $(B=-1.123, p=.013)$. Artinya, semakin rendah dismissive maka kerentanan perempuan remaja akhir untuk menjadi korban kekerasan psikologis dalam pacaran semakin tinggi.

Tujuan dari penelitian ini adalah untuk mengetahui apakah insecure attachment (precoccupied, dismissive, dan fearful avoidant) berpengaruh terhadap kerentanan perempuan remaja akhir untuk menjadi korban kekerasan psikologis dalam pacaran. Diantara ketiga jenis insecure attachment, yang paling besar kontribusinya dalam menjelaskan kerentanan perempuan remaja akhir untuk menjadi korban kekerasan psikologis dalam pacaran adalah fearful avoidant.

Hasil ini sesuai dengan temuan penelitian yang dilakukan oleh Yarkovsky (2016) bahwa pola insecure attachment yang terbentuk dalam diri individu berhubungan dengan tingginya tingkat kesulitan dalam meregulasi emosi, dimana hal ini berhubungan dengan kecenderungan seseorang untuk menjadi korban maupun pelaku kekerasan. Individu dengan insecure attachment cenderung sulit untuk melepaskan diri dari pasangan meskipun hubungan yang dijalani merupakan hubungan yang penuh dengan tekanan. Hal ini memungkinkan seseorang untuk mengalami kekerasan dalam pacaran, salah satunya adalah kekerasan psikologis.

Berdasarkan penelitian yang telah dilakukan, fearful avoidant berpengaruh lebih besar dalam memprediksi perempuan usia remaja akhir untuk menjadi korban kekerasan psikologis dalam pacaran daripada preoccupied. Hal ini disebabkan fearful avoidant adalah jenis attachment yang paling tidak aman dan tidak adaptif dicirikan dengan tingginya tingkat anxiety dan avoidant. Individu dengan jenis attachment ini memiliki pandangan negatif terhadap diri sendiri dan orang lain dalam hal ini pasangan (Bartholomew, 1990). Pandangan negatif terhadap diri sendiri menjadikan mereka tidak merasa layak untuk dihargai oleh pasangan, tidak mampu menyelesaikan permasalahan dalam hubungan secara mandiri.

Hasil dari adanya pandangan negatif terhadap diri sendiri membuat individu dengan fearful avoidant tidak memiliki rasa percaya diri yang baik. Selain itu, fearful avoidant dicirikan dengan adanya rasa tidak nyaman jika dekat dengan orang lain akibat adanya kekhawatiran bahwa pasangan akan menyakitinya (Bartholomew, 1990). Ketakutan akan disakiti oleh pasangan dan model diri yang negatif membuat individu dengan jenis attachment ini kerapkali berada dalam hubungan yang penuh tekanan. Selain itu, model diri yang negatif membuat individu dengan fearful avoidant memiliki self esteem yang rendah (Mikulincer \& Shaver, 2016) dimana hal ini berhubungan dengan adanya perasaan tidak berharga sehingga memungkinkan seseorang untuk terlibat dalam hubungan yang mengandung kekerasan salah satunya kekerasan psikologis karena merasa dirinya tidak mampu untuk mengambil jalan keluar.

Individu dengan fearful avoidant cenderung menghindar jika orang lain 
mendekatinya. Meskipun begitu, individu dengan fearful avoidant sebenarnya menginginkan hubungan emosional yang dekat dan cenderung sangat bergantung dengan orang lain. Hasil penelitian ini juga menunjukkan bahwa jenis preoccupied juga memiliki pengaruh terhadap kerentanan perempuan remaja akhir untuk menjadi korban kekerasan psikologis dalam pacaran. Artinya, attachment ini dapat menjadi salah satu faktor yang membuat seseorang mengalami kekerasan psikologis dalam pacaran. Jenis kelekatan ini dicirikan dengan memiliki model negatif atas diri sendiri dan positif pada orang lain serta berhubungan dengan tingginya tingkat anxiety (Bartholomew, 1990).

Tingkat anxiety yang tinggi membuat individu memiliki ketakutan jika ditinggalkan oleh pasangannya. Ketakukan ini menjadi alasan untuk tetap bertahan dalam situasi apapun termasuk menjadi korban kekerasan psikologis dalam pacaran secara berulang. Asumsi mereka ialah lebih baik berada dalam hubungan yang mengandung kekerasan daripada tidak memiliki pacar atau figur lekat sebagai sumber kebahagiaan. Hal ini juga disebabkan oleh adanya model positif terhadap pasangan sehingga membuat mereka berpikir bahwa pasangan adalah sumber kebahagiaan dan pemenuh kebutuhan.

Preoccupied dicirikan dengan avoidant yang rendah, selain itu juga dicirikan dengan gaya hubungan yang posesif (Mikulincer \& Shaver, 2016). Rendahnya tingkat avoidant membuat individu sulit untuk melepaskan diri dari hubungan yang mengandung kekerasan. Hal ini disebabkan oleh ketidakmampuan untuk menyelesaikan permasalahan dalam hubungan secara mandiri. Oleh karenanya, semakin memperkuat bahwa individu dengan tipe attachment ini akan mengalami kekerasan psikologis dalam pacaran karena ketidakmampuan untuk melepaskan diri dari pasangan.
Hasil dalam penelitian ini juga menunjukkan hasil bahwa salah satu jenis attachment yaitu dismissive berpengaruh negatif signifikan terhadap kekerasan psikologis dalam pacaran. Artinya, semakin rendah tingkat dismissive maka kerentanan seseorang untuk menjadi koban kekerasan psikologis dalam pacaran semakin tinggi. Jenis kelekatan ini ditandai dengan adanya model positif pada diri sendiri dan model negatif pada orang lain serta dicirikan dengan tingginya tingkat avoidance (Bartholomew, 1990). Dismissive attachment dicirikan oleh tingginya tingkat avoidance dimana hal ini berhubungan dengan bagaimana seseorang bereaksi dalam peristiwa mengancam.

Mikulincer dan Shaver (2016) menyatakan bahwa individu dengan tingkat avoidance yang tinggi mempertahankan self image yang positif melalui unconscious defense dan perilaku narcissistic (defensive self enhancement). Mereka belajar untuk tidak fokus dan tidak peduli akan situasi mengancam serta tidak menjadikan figur lekat sebagai sumber dukungan. Usaha dalam melakukan perilaku defensif disertai oleh penyangkalan akan ketidakmampuan diri dan self aspects yang negatif. Individu dengan tingkat avoidance yang tinggi juga berusaha menjaga tingkat self esteem agar tetap tinggi dengan melakukan perilaku defensif. Individu dengan dismissive attachment merasa mampu hidup nyaman tanpa memiliki hubungan emosional yang dekat dengan orang lain.

Model diri yang positif membuat individu dengan tipe dismissive merasa dirinya sempurna, berharga, layak untuk dicintai, dan memiliki power dalam sebuah hubungan (Mikulincer \& Shaver, 2016). Model negatif terhadap pasangan menjadikan individu cenderung menghindar dalam hubungan karena menganggap bahwa orang lain tidak mampu membahagiakan dan tidak mampu memenuhi kebutuhannya. Hal ini membuat adanya perasaan tidak nyaman jika bergantung pada orang lain, dan tidak 
nyaman jika orang lain bergantung pada dirinya. Berbeda halnya jika tingkat dismissive rendah, seseorang akan lebih bergantung pada pasangan dimana hal ini dapat membuat individu terjebak dalam hubungan yang mengandung kekerasan.

\section{Simpulan}

Penelitian ini menyimpulkan bahwa remaja perempuan dengan insecure attachment memiliki kemampuan yang rendah dalam menghadapi konflik sehingga rentan untuk mengalami kekerasan dalam berpacaran. Mereka tidak mampu untuk mengutarakan apa yang dirasakan dalam hubungan pada pasangan yang berdampak ketika pasangan memberikan perlakuan yang tidak menyenangkan maka mereka akan cenderung diam dan menerima. Lebih jauh lagi, perilaku-perilaku kekerasan yang terjadi dianggap hal yang wajar oleh kedua belah pihak dalam hubungan tersebut. Selain dampaknya adalah semakin mempersulit diri korban untuk meninggalkan hubungan, individu juga tidak memiliki kuasa yang penuh untuk mengendalikan hubungan sehingga membuatnya semakin lemah dan rentan untuk terus menjadi korban kekerasan psikologis dalam pacaran. Dampak terburuk yang mungkin terjadi adalah individu tidak memiliki jalan keluar akibat merasa diri dan pasangannya tidak berharga, sehingga pada akhirnya tetap bertahan dalam hubungan yang selalu diwarnai kekerasan.

\section{Daftar Pustaka}

Alvarez, C. D. (2014). What do the dating violence scales measure? Social and Behavioral Sciences, 161, 18-23.

Anastasi, A., \& Urbina, S. (2007). Tes psikologi. Edisi ke tujuh (terjemahan). PT. Indeks.

Azwar, S. (2016). Penyusunan skala psikologi. Pustaka Pelajar.

Bartholomew, K. (1990). Avoidance of intimacy: An attachment perspective.
Journal of Social and Personal Relationships, 7, 147-178.

Bartholomew, K., Horowitz, L. M. (1991). Attachment styles among young adults: A test of a four-category model. Journal of Personality and Social Psychology, 61, 226-244.

Bowlby, J. (1983). Attachment and loss. Basic Books.

Cortes-Ayala, M. L., Bringas, C., Rodriguez-Franco, L., Flores, M., Ramiro-Sanchez, T., \& Rodriguez, F. J. (2014). Unperceived dating violence among Mexican students. International Journal of Clinical and Health Psychology, 14, 39-47.

Diadiningrum, J. R., \& Endrijati, H. (2014). Hubungan antara sikap asertivitas dengan kecenderungan menjadi korban kekerasan dalam pacaran pada remaja. Jurnal Psikologi Pendidikan dan Perkembangan Universitas Airlangga, 3(2), 97-102.

Stark, S. W. (2015). Emotional abuse. Psychology \& Behavioral Health $4^{\text {th }}$ ed. Greyhouse Publishing

Erdianto, K. (2016). Tak ada payung hukum sebabkan angka kekerasan dalam pacaran relatif tinggi. Kompas.com.

https://nasional.kompas.com/read/2016 /03/07/18102311/Tak.Ada.Payung.Huk um.Sebabkan.Angka.Kekerasan.dalam. Pacaran.Relatif.Tinggi.

Exner-Cortens, D. (2018). Measuring Adolescent Dating Violence. In Adolescent Dating Violence (pp. 315340). Elsevier Inc. https://doi.org/10.1016/b978-0-12811797-2.00013-x

Griffin, D. W., \& Bartholomew, K. (1994). The methaphysics of measurement: The case of adult attachment. Advances in Personal Relationship, 5, 17-52.

Hazan, C., \& Shaver, P. (1994). Attachment as an organizational framework for research on close relationship. Psychological Inquiry, 5(1), 1-22. 
Khaninah, A. N., \& Wijanarko, N. (2015). Perilaku agresif yang dialami korban kekerasan dalam pacaran. Jurnal Psikologi Universitas Diponegoro, 15(2), 151-160.

Komnas perempuan. (2017). Lembar fakta catatan tahunan komnas perempuan tahun 2017. https://www.komnasperempuan.go.id/f ile/pdf file/2017\%20Siaran\%20Pers/L embar\%20Fakta\%20Catahu\%202017.p $\underline{\mathrm{df}}$

Jennings, W. G., Okeem, C., Piquero, A. R., Sellers, C. S., Theobald, D., \& Farrington, D. P. (2017). Dating and intimate partner violence among young persons ages 15-30: Evidence from a systematic review. Agression and Violent Behavior, 33, 1-19.

Lee, M., Weber, M. R.., \& Khan, Jeffey. (2014). Exposure to family violence and attachment styles as predictors of dating violence perpetration among men and women: A mediational model. Journal of Interpersonal Violence, 29(1), 20-43.

Mikulincer, M., \& Shaver, P. R. (2016). Attachment in adulthood: Structure, dynamics, and change $\left(8^{\text {th }} e d\right)$. The Guliford Press.

Millett, L. S., Seay, K. D., \& Kohl, P. L. (2015). A national study of intimate partner violence risk among female caregivers involved in the child welfare system: The role of nativity, acculturation, and legal status. Children and Youth Services Review, 48, 60-69.

Moreno-Manso, J. M., Blazquez-Alonso, M.,Garcia-Baamonde, M. E., Guerrero-Barona, E., \& PozuecoRomero, J. M. (2014). Gender as an explanatory factor of psychological abuse in datingcouples. Journal of Social Service Research, 40, 1-14.

Papalia, D. E., \& Feldman, R. D. (2014). Menyelami perkembangan manusia. Salemba Empat.
Purnomo, F. H., \& Suryadi. (2017). The effect of attachment style and religiousity toward dating violence among adolescent. Jurnal Psikologi Tazkiya, 22(2), 217-230.

Reyes, H. L. M., Foshee, V. A., Niolon, P. H., Reidy, D. E., \& Hall, J. E. (2016). Gender role attitudes and male adolescent dating violence perpetration: Normative beliefs as moderators. Journal of Youth Adolescene, 45, 350-360.

Taskale, N., \& Soygut, G. (2016). Risk factors for women's intimate partner violence victimization: An examination from the perspective of the schema therapy model. Journal of Family Violence, 32, 3-12.

Temple, J. R., Choi, H. J., Elmquist, J., Hecht, M., Miller-Day, M., Stuart, G. L., Brem, M., \& Woldfor-Clevenger, C. (2016). Psychological abuse, mental health, and acceptance of dating violence among adolescents. Journal of Adolescent Health, 30, 1-6.

Tussey, B. E., Tayler, K. A., \& Simons, L. G. (2018). Poor parenting, attachment style, and dating violence perpetration among college students. Journal of Interpersonal Violence, 00, 1-20.

Ulloa, E. C., Martinez-Arango, N., \& Hokoda, A. (2014). Attachment anxiety, depressive symptoms, and adolescent dating violence perpetration: A longitudinal mediation analysis. Journal of Aggression, Maltreatment, and Trauma, 23(6), 652-669.

Urena, J., E. M. Romera., Casas, O. A., Viejo, C., \& Ortega-Ruiz, R. (2015). Psichometrics properties of psychological dating violence questionnaire: A study with young couples. Journal of Clinical and Health Psychology, 15, 52-60.

Wang, L. (2016). Factors influencing attitude toward intimate partner violence. Aggression and Violent Behavior, 29, 1-7. 
Wekerle, C., \& Wolfe, D. (1999). Dating violence in mid adolescent: Theory, significance, and emerging prevention initiative. Clinical Psychology Review, 19(4), 435-456.

Wolfe, D. A., Wekerle, C., Gough, R., Reitzel-Jaffe, D., Grasley, C., Pittman, A., \& Stumpf, J. (1996). Youth relationships manual: A group approach with adolescents for the prevention of woman abuse and the promotion of healthy relationships. Sage.

Wolfe, D. A., Scott, K., Reitzel-Jaffe, D., Wekerle, C., Grasley, C., \& Straatman, A. (2001). Development and validation of the conflict in adolescent dating relationships inventory. Psychological Assessment, 13, 277-293.
Wolfe, D. A., \& Feiring, C. (2002). Dating violence and adolescent romance. Journal of Child Maltreatment, 5(4), 360-363.

Wolfe, D. A., Scott, K. L., \& Crooks, C. V. (2005). Abuse and violence in adolescent girls' dating relationships. Dalam D. J. Bell, S. L. Foster, \& E. J. Mash (eds.), Handbook of behavioral and emotional problems in girls. Plenum Publishers.

Yarkovsky, N. (2016). Experiences of dating violence in emerging adult couples: The role of attachment style and emotion regulation (Thesis), University of Windsor. 
Psympathic, Jurnal Ilmiah Psikologi Desember 2019, Vol. 6, No. 2, Hal. : 181-190 